\title{
Correction to: Between Collaboration and Subordination: State and Non-state Actors in Russian Anti-drug Policy
}

\author{
Aadne Aasland $^{1} \cdot$ Sabine Kropp $^{2}$ (1) $\cdot$ Anastasia Y. Meylakhs $^{3}$
}

Published online: 12 August 2020

(c) International Society for Third-Sector Research 2020

\section{Correction to:}

Voluntas (2020) 31:422-436

https://doi.org/10.1007/s11266-019-00158-9

Publisher's Note Springer Nature remains neutral with regard to jurisdictional claims in published maps and institutional affiliations.

This paper was intended for the present special section Civil Society in Authoritarian and Hybrid Regimes, but published previously.

The original article can be found online at https:// doi.org/10.1007/s11266-019-00158-9.

Sabine Kropp

sabine.kropp@fu-berlin.de

Aadne Aasland

aadnea@oslomet.no

Anastasia Y. Meylakhs

nastia.meylakhs@gmail.com

1 The Norwegian Institute for Urban and Regional Research (NIBR), Oslo Metropolitan University, St. Olavs Plass, 0130 Oslo, Norway

2 Chair of German Politics, Otto-Suhr Institute of Political Science, Freie Universität Berlin, Ihnestr. 22, 14195 Berlin, Germany

3 International Centre for Health Economics, Management, and Policy, National Research University Higher School of Economics, Kantemirovskaya St., 3 A, Office 408, Saint Petersburg, Russian Federation 194100 